\title{
Growth Response of Indian Spinach to Biogas Plant Residues
}

\author{
N. Hossain ${ }^{1}$, M. Islam ${ }^{2}$, M. Alamgir ${ }^{3}$ and M.G. Kibria ${ }^{4}$ \\ 1, 2, 3,4 Department of Soil Science, University of Chittagong, Chittagong 4331, Bangladesh
}

\begin{abstract}
A pot experiment was conducted to study the growth response of Indian spinach (Basella alba $\mathrm{L}$ ) to biogas plant residues. There were seven treatments comprising of control, recommended NPK fertilizer and biogas plant residues (BPR)@ 10,20,30,40 and 50 ton ha $\mathrm{I}^{-1}$. The treatments were arranged in a randomized complete block design with three replications. Results indicated that number of leaves; plant height and root length and dry weight of shoot and root obtained with recommended NPK fertilizer were statistically similar to those with control treatment except for number of leaves at 60 DAS. Application of biogas plant residues up to 30 ton ha ${ }^{-1}$ produced similar number of leaves and plant height compared to control and recommended NPK fertilizer at 30 DAS. At 60 DAS, a significantly higher number of leaves and root length was found with above 20 ton ha $a^{-1}$ biogas plant residues and plant height with above 10 ton ha ${ }^{-1}$ biogas plant residues than control and recommended NPK fertilizer. Fresh weight of shoot and root found with recommended fertilizer dose were significantly higher than that with the control but lower than that with biogas plant residues above 30 ton hal and 10 ton ha ${ }^{-1}$, respectively. Biogas plant residues at 30 ton ha $a^{-1}$ and above gave higher shoot and root dry weight than control and recommended NPK fertilizer. However, there were no significant differences between BPR40 and BPR50 for growth parameters of Indian spinach. The study recommends 40 ton hal of biogas plant residues for enhanced growth of Indian spinach.
\end{abstract}

Key words: biogas plant residues, Indian spinach, plant height, shoot and root weight.

\section{Introduction}

Indian spinach (Basella alba $\mathrm{L}$ ) is a popular tropical leaf green vegetable commonly used in the diet of human beings. Commonly found in the home gardens of many south Asian families, it is gaining popularity in some of the tropical and temperate climates of America, Australia and Europe for its succulent, nutritious greens, and tender stems. Indian spinach is a very versatile leaf green vegetable and revered in some East Asian cultures for its wholesome phyto-nutrients profile. It contains an incredibly good amount of vitamins, minerals, and antioxidants [1]. Indian spinach leaves and stem are incredibly rich sources of vitamin A and vitamin C. This green leafy vegetable also contains good amounts of many B-complex vitamins such as folate, vitamin-B6 (pyridoxine), and riboflavin. Basella leaves are very rich sources of minerals like potassium (11\% of RDA/100 $\mathrm{g}$ ), manganese ( $32 \%$ of RDA/100 g), calcium, magnesium, and copper [1]. Potassium is an important component of cell and body fluids that helps controlling heart rate and blood pressure. Manganese and copper are used by the body as a co-factor for the antioxidant enzyme, superoxide dismutase. Indian spinach is an excellent source of iron, an important trace element, required by the human body for red blood cell (RBC's) production. Fresh leaves of Indian spinach are rich sources of several vital carotenoid pigment anti-oxidants such as $\beta$-carotene, lutein, zea-xanthin. These compounds play a healing role in aging and various disease processes [1]. Indian spinach has been used from a long time back for the treatment of many diseases like dysentery, diarrhea, anemia, cancer etc [2]. In Bengali cuisine, Indian spinach is widely used both in a vegetable dish, cooked with red pumkin, and in a non-veg dish, cooked with fishes especially with Hilsha fish.

Bangladesh is an agricultural country where limited cultivable land is forced to maximize crop yields per unit area through intensive use of land and soil resources. Due to the present land ownership and tenure ship the farmers of Bangladesh have the tendency to exploit the soils for maximum profit and little attention is given for maintaining sustainable soil health. The soil fertility and productivity of soils of Bangladesh has been declining day by day due to continuous mining of nutrients, crop intensification and imbalanced use of chemical fertilizers with little or no addition of organic fertilizers. Organic matter content in Bangladesh soil is alarmingly low around $1 \%$ in most and $2 \%$ in few soils, where it should be maintained at least 3\% that is conducive to high productivity [3]. Under such situation to increase soil fertility and sustain crop productivity, there is no alternative besides to add organic fertilizer into the soil. Organic fertilizer can serve as a substitute to mineral fertilizers. Despite the large quantities of plant nutrients contained in inorganic fertilizers as compared to organic nutrients, the presence of growth promoting agents in organic fertilizers make them important for enhancement of soil fertility and productivity [4]. Organic fertilizers play a vital role in restoring fertility as well as organic matter status of the soils.

The residues obtained from the biogas plant may be considered as a good source of organic fertilizer as it contains considerable amounts of both macro and micro nutrients $[5,6]$. There is an increasing trend in 
installing biogas plants in Bangladesh to meet energy requirements. Biogas technology is becoming popular in rural Bangladesh in view of escalating costs of fuels as well as soaring prices of chemical fertilizers which our farmers find difficult to buy for their sustainable crop production. More than 25,000 biogas plants of varying gas-producing capacities (2-6 m3) run with cow dung and poultry litter for domestic purposes and some large sized ones in poultry farms are in operation in the country [3]. The organic materials generally used in Bangladesh as raw materials for biogas plant are cow dung, poultry litter, water hyacinth and crop residues. Yield responses of vegetable crops to bio-slurry manure application have been reported in different crops including okra[7] maize and cabbage [8]. The use of cow dung biogas residues in Indian spinach production has not been tested in Indian spinach growing areas especially in Bangladesh. This study is therefore aimed at investigating the potential use of cow dung biogas plant residues to enhance growth of Indian spinach.

\section{1. Pot experiment}

\section{Materials and Methods}

A pot experiment was conducted to study the effects of biogas plant residues on growth Indian spinach (Basella alba L). Soil used in the pot experiment was collected from the crop field of the Department of Soil Science, University of Chittagong. Soil samples were air dried, larger and massive aggregates were broken down by gentle crushing with wooden pluck. Dry roots, grasses and other particulate materials were removed from the soil and processed for pot experiment. Eight kilograms soil was placed in each earthen pot. For the study, residues of biogas plant were collected from a biogas plant established at Jubra village nearby Chittagong University. There were seven treatments comprising of biogas plant residues (BPR) and NPK fertilizers as follows-

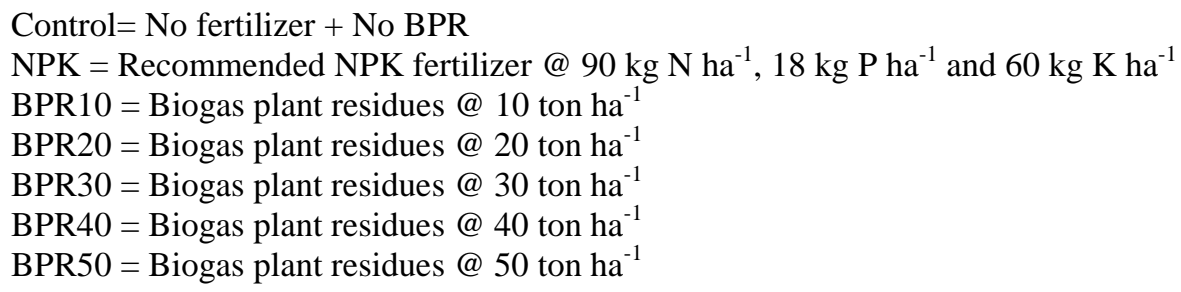

The fertilizer doses of N, P and K were applied from Urea, TSP and MP, respectively. According to Bangladesh Agricultural Research Council [9] recommendation, half $\mathrm{N}$ and $\mathrm{K}$, and whole of $\mathrm{P}$ were applied during soil preparation. Remaining $\mathrm{N}$ and $\mathrm{K}$ were applied in two equal installments after 2 and 4 weeks of seedling emergence. All of biogas plant residues were applied as basal during soil preparation and soils mixed with biogas plant residues were allowed to equilibrate for 4 weeks prior to sowing seeds. Each treatment was replicated thrice and the pots were arranged in randomized block design. Five healthy and uniform seeds of Indian spinach were sown at equal distance in each pot. After two weeks of seedling emergence, two seedlings were kept in each pot. Care was taken to keep uniform seedlings in the pots. Irrigation was applied as and when necessary. The experimental pots were kept free of weeds by regular weeding. To control the pests and diseases, necessary plant protection measures were done as and when required.

\section{2. Data collection}

Plant height and number of leaves were recorded at 30 and 60 days after sowing (DAS) to assess plant growth. Plants were harvested a 60 DAS. At harvest root samples were separated from shoots and washed carefully to remove any soil. Fresh and oven dry $\left(65^{\circ} \mathrm{C}\right.$ to constant weight) weights of shoots and roots were recorded.

\section{3. Analysis of soil and biogas plant residues}

Soil texture was determined by hydrometer method [10], soil $\mathrm{pH}$ was measured in a 1:2.5 soil/water suspension with glass electrode $\mathrm{pH}$ meter, organic carbon by wet-oxidation method [11], total nitrogen by micro-Kjeldahl digestion and distillation and CEC by $1 \mathrm{~N} \mathrm{NH4OAC}$ saturation [12], and available phosphorus by Olsen method [13]. The same methods used for soil were followed for the determination of properties of biogas plant residues. The experimental soil was clay loam (33\% sand, $19 \%$ silt and $48 \%$ clay) with pH 5.10, organic matter content $1.32 \%$, cation exchange capacity (CEC) $8.76 \mathrm{cmol} \mathrm{kg}^{-1}$, total nitrogen $0.12 \%$, and available $\mathrm{P}$ (Olsen P) $14 \mathrm{mg} \mathrm{kg}^{-1}$. Biogas plant residues used in the experiment contained $\mathrm{pH} 5.96$, total nitrogen $0.28 \%$, available P $13.17 \mathrm{mg} \mathrm{kg}^{-1}$. 


\section{4. Statistical analysis}

The significance of differences between the means of the treatments was evaluated by one way analysis of variance followed by Duncan's Multiple Range Test at the significance level of 5\%. The statistical software Excel [14] and SPSS version 12 [15] were used for these analyses.

\subsection{Number of leaves}

\section{Results and Discussion}

The number of leaves of Indian spinach was recorded at 30 and 60 days after sowing (DAS). Significant variation in number of leaves was observed among the treatments. Number of leaves tended to be increased with increasing BPR application. The highest number of leaves was obtained with BPR50 followed by BPR40 and the lowest number of leaves was found with control treatment both at 30 and 60 DAS (Fig. 1).The percent increase in number of leaves recorded with BPR50 compared to control was 54.13 and 79.95 at 30 and 60 DAS, respectively. Application of recommended NPK fertilizer produced significantly higher number of leaves compared to control at 60DAS but not at 30 DAS. The number of leaves found with biogas plant residues up to 30 and 20 ton ha $^{-1}$ was statistically similar with that of control treatment at 30 and 60 DAS, respectively.

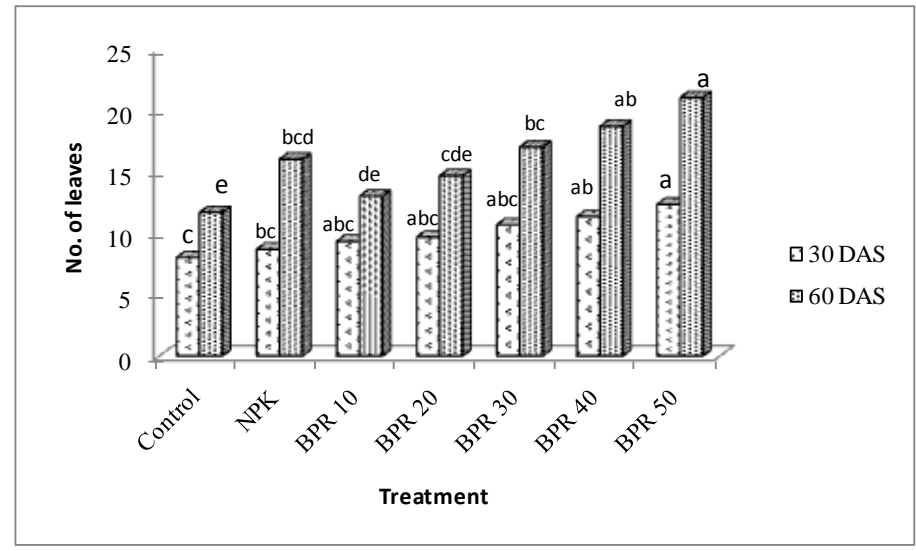

Fig. 1 Effects of biogas plant residues on number of leaves of Indian spinach.

\subsection{Plant height}

The growth of Indian spinach in terms of shoot height in different treatments is shown in Fig. 2. Plant height among the treatments varied from 9.42 to $13.92 \mathrm{~cm}$ and 17.83 to $29.33 \mathrm{~cm}$ at 30 and 60 DAS, respectively. The highest plant height was observed in BPR50 and BPR40 at 30 and 60 DAS, respectively while the lowest plant height was found with control treatment at both the periods. Plant height with NPK fertilizer was statistically similar with that of control treatment at both the periods. Similar results were found with application of biogas plant residues up to 30 ton ha $^{-1}$ at 30 DAS. At 60 DAS, application of biogas plant residues above 10 ton ha ${ }^{-1}$ produced significantly higher plant height compared to control treatment. However, there were no significant differences in plant height among the treatments BPR20, BPR30, BPR40 and BPR50 at both the periods. Plant height was increased by $47.77 \%$ and $64.50 \%$ with 50 ton ha ${ }^{-1}$ biogas plant residues compared to control at 30 and 60 DAS, respectively.

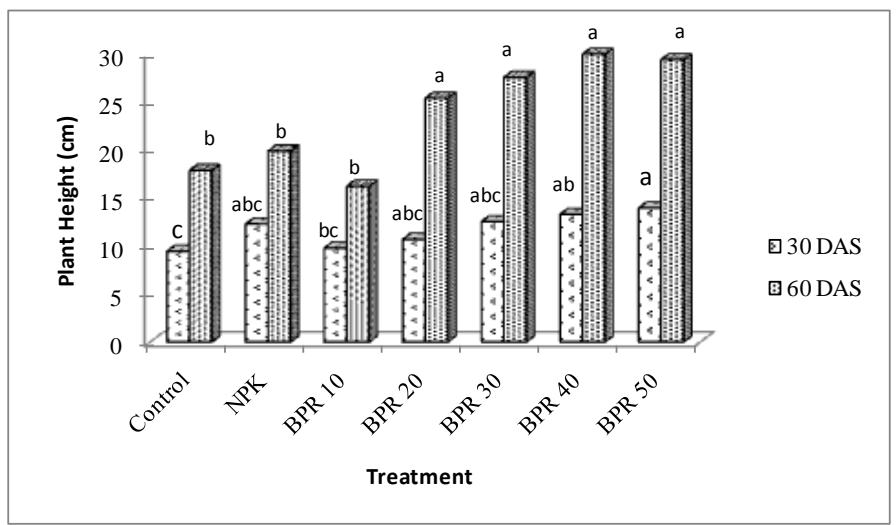

Fig. 2 Effects of biogas plant residues on plant height of Indian spinach. 


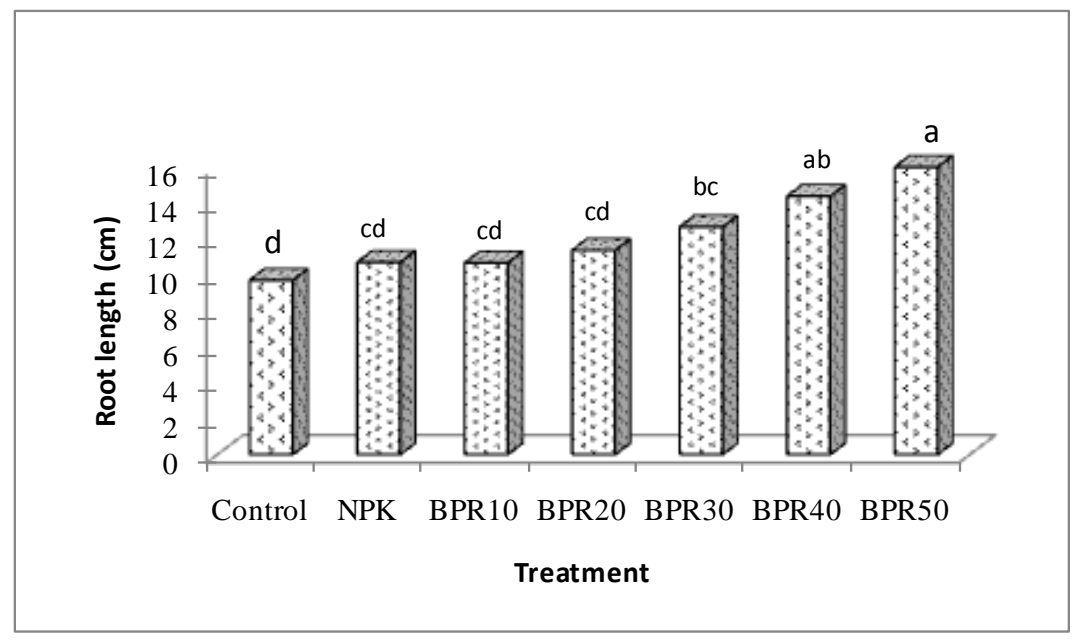

Fig. 3 Effects of biogas plant residues on root length of Indian spinach.

\subsection{Root length}

Root length of Indian spinach varied significantly from $9.70 \mathrm{~cm}$ in the control to $16.00 \mathrm{~cm}$ in BPR50. Root length increased with increasing rate of BPR but no significant difference in root length among BPR10 to BPR30 was observed (Fig. 3). The root length obtained with recommended NPK fertilizers and biogas plant residues up to 20 ton $\mathrm{ha}^{-1}$ were statically similar to that found with control treatment. Although biogas plant residues above 20 ton $\mathrm{ha}^{-1}$ gave significantly higher root length than control but there was no significant difference in root length between BPR30 and BPR40 and between BPR40 and BPR50.

\subsection{Fresh weight of shoot and root}

The variation in growth response of Indian spinach in terms of fresh weight of shoot and root is presented in Fig. 4. Fresh weight of shoot and root varied from 28.71 to $68.60 \mathrm{~g} \mathrm{pot}^{-1}$ and 2.22 to $4.15 \mathrm{~g} \mathrm{pot}^{-1}$, respectively. Compared to the control (no residues and no inorganic NPK fertilizers), BPR applied at a rate of 50 ton ha ${ }^{-1}$ resulted in the greatest increase in shoot and root fresh weight (2.39 and 1.87 fold respectively). Fresh weight of shoot and root found with recommended fertilizer dose were significantly higher than that with the control but lower than that with biogas plant residues above 30 ton ha ${ }^{-1}$ and 10 ton $\mathrm{ha}^{-1}$, respectively. There were no significant differences in fresh weight of shoot and root between BPR40 and BPR50.

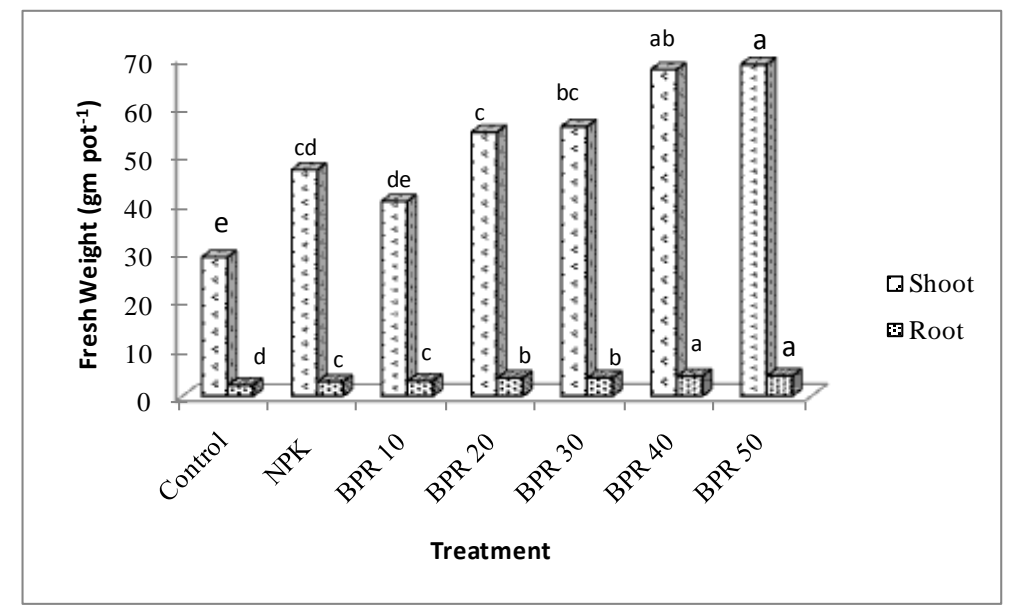

Fig. 4 Effects of biogas plant residues on fresh weight of shoot and root of Indian spinach.

\subsection{Dry weight of shoot and root}

Dry weight of shoot ranged from 1.56 to $3.79 \mathrm{~g} \mathrm{pot}^{-1}$ and root from 0.33 to $0.67 \mathrm{~g} \mathrm{pot}^{-1}$, respectively. The highest dry weight of shoot and root was observed in treatment BPR50 and the lowest dry weight of shoot and root was found in control treatment. The second highest dry weight of shoot and root was found with BPR40 followed by BPR30. However, there were no significant differences among BPR50, BPR40 and 
BPR30.Application of recommended NPK fertilizer and biogas plant residues up to 20 ton ha ${ }^{-1}$ produced similar shoot and root dry weight compared to control treatment.

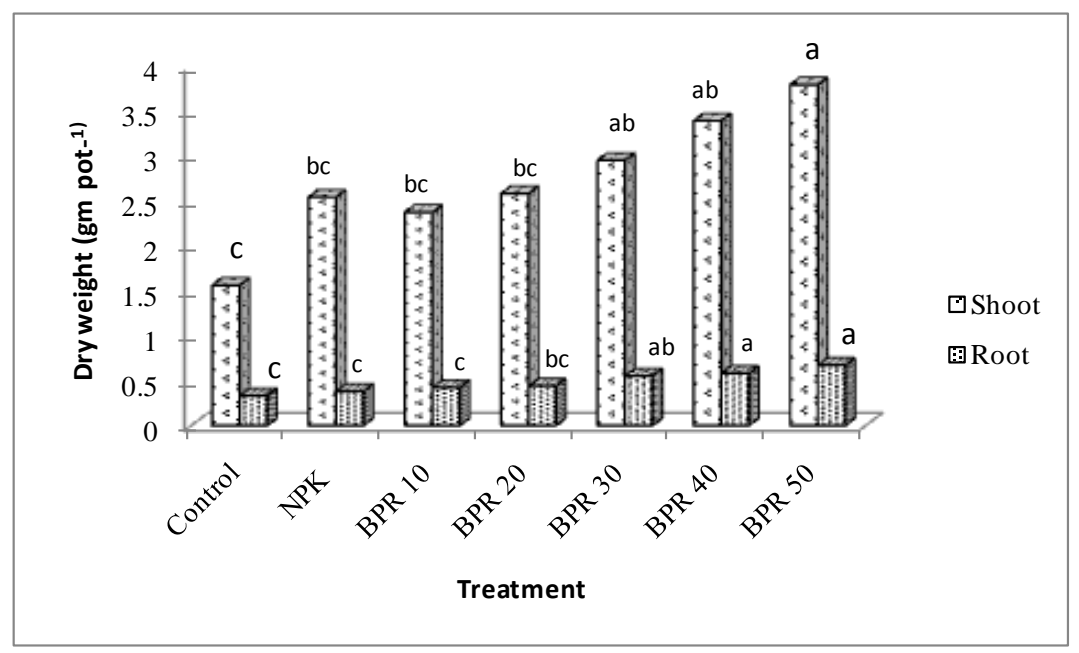

\section{Fig. 5 Effects of biogas plant residues on dry weight of shoot and root of Indian spinach.}

The significant increase in growth parameters of Indian spinach due to biogas plant residues and NPK fertilizer confirm the deficiency of organic matter, $\mathrm{N}$ and $\mathrm{P}$ in the soil and biogas plant residues as effective source of plant nutrients. Nitrogen, phosphorus and potassium are essential for good growth of plants. In the present study, higher leaf numbers and plant heights obtained could also be attributed to better levels of major nutrients in the biogas plant residues. According to Islam [3], cow dung bio-slurry contains $1.29 \% \mathrm{~N}, 2.80 \% \mathrm{P}$ and $0.75 \% \mathrm{~K}$. Biomass of Indian spinach also tended to increase with every successive increase in biogas plant residues level. In conformity with the present findings a study by Rivard et al. [16] showed that dried and composted biogas residue produced from municipal solid waste induced an increase in crop weight (i.e., corn) and plant yield in direct proportion to the residue application rate. These findings would be attributed to improved nutrient availability and better soil structure that could have favored shoots and root growth. Organic manures are known to have the ability to supply both macro and micro nutrients required for crop growth, development and final economic yield [17].

It is of great significant and interesting issue that how effectively biogas residue can substitute common artificially produced mineral fertilizers in terms of crop yield. The potential of biogas residue in crop yield was recently reported by Montemurro et al. [18]. They found no significant differences in the cumulative plant dry weight of alfalfa subjected to different fertilizer treatments (anaerobic digestate and mineral fertilizers), whereas for cocksfoot crops, mean yield was higher in plots treated with biogas residue in relation to control plots during a two-year field experiment. Chantigny and colleagues [19] reported similar fertilizer values of raw and anaerobically treated liquid swine manure to that of mineral fertilizer upon immediate incorporation into soil[19], supporting the significant potential of biogas residue as a valuable substitute and/or complement to mineral fertilizers. Furukawa and Hasegawa [20] reported that biogas residue produced from source-separated household waste was comparable to NPK fertilizers in terms of early $\mathrm{N}$ uptake, fresh yield, and $\mathrm{N}$ uptake at harvest of spinach and komatsuna. Since biogas residue is rich in $\mathrm{NH}^{4+}-\mathrm{N}$ and $\mathrm{K}$ but low in $\mathrm{P}$ [21], and soilexchangeable $\mathrm{K}$ is high [20], its fertilizer value may be mainly attributed to the $\mathrm{N}$ effect [20]. It is important to remember that $\mathrm{N}$ is the most common limiting factor for crop growth in organic farming systems [22,23] owing to failure in synchronizing crop $\mathrm{N}$ demand and supply to the soil by mineralization of organic fertilizers [24]. In general, biogas residue presents an efficient nitrogen source for plants with the potential to improve crop yield and soil properties $[25,26]$.

\section{Conclusion}

Amending soils with biogas plant residues enhanced the vegetative growth of Indian spinach. Among the rates of tested biogas plant residues, the rate of 40 ton $^{-1}{ }^{-1}$ proved to be the best in enhancing the vegetative growth of Indian spinach. More research on testing different rates under different soil agro ecological zone conditions may be beneficial in coming up with specific rates for the different production area. 


\section{References}

[1] Annonymous, Basella (vine or Malabar spinach) nutrition facts and health benefits. Available onhttp://www.nutrition-andyou.com/basella.html.2013, Accessed on 09.12.13.

[2] R.Adhikari, H. N. Naveen Kumar andS. D. Shruthi, A Review on Medicinal Importance of Basellaalba L, International Journal of Pharmaceutical Sciences and Drug Research; 4(2), 2012, 110 -114.

[3] S. Islam, Use of bio-slurry as organic fertilizer in Bangladesh Agriculture, Proc.International workshop on the use of bio-slurry for domestic bio-slurry program, Bangkok, Thailand, 27-28 September, 2006.

[4] S. K. Sanwal, K. Lakminarayana, R. K. Yadav, N. Rai, D. S. Yadav and B. Mousumi, Effect of organic manures on soil fertility, growth, physiology, yield and quality of turmeric. Indian Journal of Horticulture, 64(4), 2007, 444-449.

[5] S. Bachmann, S. Wentzel, B. Eichler-Löbermann, Codigested dairy slurry as a phosphorus and nitrogen source for Zea mays L. and AmaranthuscruentusL. Journal of Plant Nutrition and Soil Science, 174, 2011, 908-915.

[6] T. Lošák, L. Musilová, A. Zatloukalová, M. Szostková, J. Hlušek, J. Fryč, T. Vítěz, M. Haitl, E. Bennewitz, A. Martensson, Digestate is equal or a better alternative to mineral fertilization of kohlrabi, ActaUniversitatisAgriculturae et SilviculturaeMendeleianaeBrunensis, 60, 2012, 91-96.

[7] M. Shahabz, Potential of bio-slurry and compost at different levels of inorganic nitrogen to improve growth and yield of okra (Hibiscus esculetusL.), M. Sc. Thesis, University of Agriculture Faisalabad, Pakistan, 2011.

[8] K. B. Karki, Response to bio-slurry Application on Maize and cabbage in Laliptur District. Final Field Research Report Submitted to Alternative Energy Promotion Centre of Ministry of Science and Technology,Pulchok,.Nepal. 2001.

[9 Fertilizer Recommendation Guide (Bangladesh Agricultural Research Council,Farmgate, Dhaka-1215,2012).

[10] P. R. Day, Particle fractionation and particle size analysis, in C. A. Black (Ed.) Methods of Soil Analysis. Part I. Agronomy Monograph, (New York: Academic Press, 1965) 545-567.

[11] A. Walkley and I. A. Black, An examination of the Degtjareff method for determining organic carbon in soils: Effect of variations indigestion conditions and of inorganic soil constituents, Soil Science, 63, 1934, 251-263.

[12] M L. Jackson, Soil Chemical Analysis (New Delhi, Prentice Hall of India Private Limited, 1973).

[13] S. Olsen, C. Cole, F. Watanabe and L. Dean, Estimation of available phosphorus in soils by extraction with sodium bicarbonate (USDA Circular No. 939, US Government Printing Office, Washington, D.C., 1954).

[14] Excel Inc., Microsoft Excel for Windows (USA, Microsoft Corporation, 2003).

[15] SPSS Inc., Statistics (Chicago, SPSS Inc. 2003).

[16] C. J. Rivard, J.B. Rodriguez, N.J. Nagle, J.R. Self, B.D. Kay, P.N. Soltanpour, R.A. Nieves, Anaerobic digestion of municipal solid waste. Utility of process residues as a soil amendment, Applied Biochemistry Biotechnology,51-52,. 1995, 125-135.

[17] M.A.J. Parry, J. Flexas and H. Medrano, Prospects for crop production under drought:research priorities and future directions, Annual Applied Biology, 147, 2005, 211-226.

[18] F. Montemurro, S.Canali, G. Convertini, D. Ferri, F.Tittarelli andC.Vitti, Anaerobic digestates application on fodder crops: effects on plant and soil,Agrochemica,52,2008, 297-312.

[19] M. H.Chantigny, D.A. Angers, G. Bélanger, P. Rochette,N. Eriksen-Hamel, S. Bittman, K. Buckley, D. Massé andM. O.Gasser, Yield and nutrient export of grain corn fertilized with rawand treated liquid swine manure,Agronomy Journal,100, 2008, 13031309.

[20] Y. Furukawa andH. Hasegawa, Response of spinach and komatsuna to biogas effluent made from source-separated kitchen garbage, Journal of Environmental Quality,35, 2006, 1939-1947.

[21] D.I. Masse, F. Croteau andL.Masse, The fate of crop nutrients during digestion of swine manure in psychrophilic anaerobic sequencing batch reactors,Bioresource Technology,98, 2007, 2819-2823.

[22] X. P. Pang andJ. Letey, Organic farming: challenge of timing nitrogen availability to crop nitrogen requirements, Soil Science Society of America Journal, 64, 2000, 247-253.

[23] K. Möller, J. Habermeyer, V. Zinkernagel,H. J. Reents, Impact and interaction of nitrogen and Phytophtorainfestansas yieldlimiting and yield-reducing factors in organic potato (SolanumtuberosumL.) crops, Potato Research, 49,2006, $281-301$.

[24]. K. Möller andW. Stinner, Effects of different manuring systems with and without biogas digestion on soil mineral nitrogen content and on gaseous nitrogen losses (ammonia, nitrous oxides), European Journal of Agronomy, 30, 2009, 1-16.

[25] R. Prasad and J.F. Power, Crop residue management, Advances in Soil Science, 15, 1991, $205-251$.

[26] H. Pathak,J.SKushwaha,. M.C. Jain, Evaluation of manurial value of biogas spent slurrycomposted with dry mango leaves, wheat straw and rock phosphate on wheat crop, Journal of Indian Society of Soil Science, 40,1992, 753-757. 